\title{
Review Article \\ P2Y Receptors in Synaptic Transmission and Plasticity: Therapeutic Potential in Cognitive Dysfunction
}

\author{
Segundo J. Guzman ${ }^{1}$ and Zoltan Gerevich ${ }^{2}$ \\ ${ }^{1}$ Institute of Science and Technology Austria (IST Austria), Am Campus 1, 3400 Klosterneuburg, Austria \\ ${ }^{2}$ Institute of Neurophysiology, Charité-Universitätsmedizin Berlin, Charitéplatz 1, 10117 Berlin, Germany \\ Correspondence should be addressed to Zoltan Gerevich; zoltan.gerevich@charite.de
}

Received 30 November 2015; Accepted 10 February 2016

Academic Editor: Francisco Ciruela

Copyright (C) 2016 S. J. Guzman and Z. Gerevich. This is an open access article distributed under the Creative Commons Attribution License, which permits unrestricted use, distribution, and reproduction in any medium, provided the original work is properly cited.

\begin{abstract}
ATP released from neurons and astrocytes during neuronal activity or under pathophysiological circumstances is able to influence information flow in neuronal circuits by activation of ionotropic P2X and metabotropic P2Y receptors and subsequent modulation of cellular excitability, synaptic strength, and plasticity. In the present paper we review cellular and network effects of P2Y receptors in the brain. We show that P2Y receptors inhibit the release of neurotransmitters, modulate voltage- and ligand-gated ion channels, and differentially influence the induction of synaptic plasticity in the prefrontal cortex, hippocampus, and cerebellum. The findings discussed here may explain how $\mathrm{P}_{2} \mathrm{Y}_{1}$ receptor activation during brain injury, hypoxia, inflammation, schizophrenia, or Alzheimer's disease leads to an impairment of cognitive processes. Hence, it is suggested that the blockade of $\mathrm{P}_{2} \mathrm{Y}_{1}$ receptors may have therapeutic potential against cognitive disturbances in these states.
\end{abstract}

\section{Introduction}

Adenosine triphosphate (ATP), the general currency in energy conversions within all living cells, was discovered in 1929 in muscle tissue $[1,2]$. In the same year, Drury and Szent-Györgyi described that ATP and its metabolite, adenosine, exhibit potent extracellular activity on the heart and coronary blood vessels [3]. Follow-up studies revealed that extracellular purines are involved in several central and peripheral physiological mechanisms [4] and in the early 1970s Burnstock suggested the existence of purinergic neurotransmission with the release of ATP and its actions on purinergic receptors $[5,6]$. In the 1980s it was suggested that ATP receptors, the so called P2 receptors, can be pharmacologically separated into two subtypes: the P2X and the $\mathrm{P} 2 \mathrm{Y}$ receptors [7]. While $\mathrm{P} 2 \mathrm{X}$ receptors are ligand-gated ion channels permeable for $\mathrm{Na}^{+}, \mathrm{K}^{+}$, and $\mathrm{Ca}^{2+}[8,9], \mathrm{P} 2 \mathrm{Y}$ receptors are coupled to $\mathrm{G}$ proteins and activate different intracellular cascades [10-12].

Eight different $\mathrm{P} 2 \mathrm{Y}$ receptors $\left(\mathrm{P}_{2} \mathrm{Y}_{1}, \mathrm{P}_{2} \mathrm{Y}_{2}, \mathrm{P}_{2} \mathrm{Y}_{4}, \mathrm{P}_{2} \mathrm{Y}_{6}\right.$, $\mathrm{P}_{2} \mathrm{Y}_{11}, \mathrm{P}_{2} \mathrm{Y}_{12}, \mathrm{P}_{2} \mathrm{Y}_{13}$, and $\mathrm{P} 2 \mathrm{Y}_{14}$ ) have been identified exhibiting a different sensitivity to ATP $\left(\mathrm{P}_{2} \mathrm{Y}_{11}\right), \mathrm{ADP}\left(\mathrm{P}_{2} \mathrm{Y}_{1}, \mathrm{P}_{2} \mathrm{Y}_{12}\right.$, and P2 $\left.\mathrm{Y}_{13}\right), \mathrm{UTP} / \mathrm{ATP}\left(\mathrm{P}_{2} \mathrm{Y}_{2}\right.$ and $\left.\mathrm{P}_{2} \mathrm{Y}_{4}\right), \mathrm{UDP}\left(\mathrm{P}_{2} \mathrm{Y}_{6}\right)$, or
UDP-glucose $\left(\mathrm{P}_{2} \mathrm{Y}_{14}\right)$ [13]. $\mathrm{P}_{1} \mathrm{Y}_{1}, \mathrm{P}_{2} \mathrm{Y}_{2}, \mathrm{P}_{2} \mathrm{Y}_{4}, \mathrm{P}_{2} \mathrm{Y}_{6}$, and $\mathrm{P}_{2} \mathrm{Y}_{11}$ receptors are coupled to $\mathrm{Gq}$ proteins, the activation of which stimulates phospholipase $C$ and subsequent release of $\mathrm{Ca}^{2+}$ from intracellular stores and activation of protein kinase $\mathrm{C}$ in response to inositol 1,4,5-trisphosphate and diacylglycerol production, respectively $[13,14]$. The $\mathrm{P}_{2} \mathrm{Y}_{11}$ receptor can also couple to Gs stimulating adenylate cyclase and increasing generation of cAMP [15]. $\mathrm{P}_{2} \mathrm{Y}_{12-14}$ receptors couple to Gi, effectively inhibiting adenylate cyclase and decreasing cAMP production [13].

P2Y receptors are expressed ubiquitously in the body, including the central nervous system (CNS) [16]. In the CNS, they are localized on neurons, astrocytes, oligodendrocytes, and microglia with physiological roles in neurotransmission, neurogenesis, and glial cell communication $[5,17-20]$ while they are also involved in a number of peripheral pathophysiological processes, including inflammation, ischemia, and pain [21-27].

ATP can be released from different cell types of the brain such as neurons [28,29], astrocytes [30], and microglia $[31,32]$ through exocytotic release mechanism [33], connexin/pannexin hemichannels [34], or P2X7 receptors [35]. After release of ATP, it takes approximately $200 \mathrm{~ms}$ before 


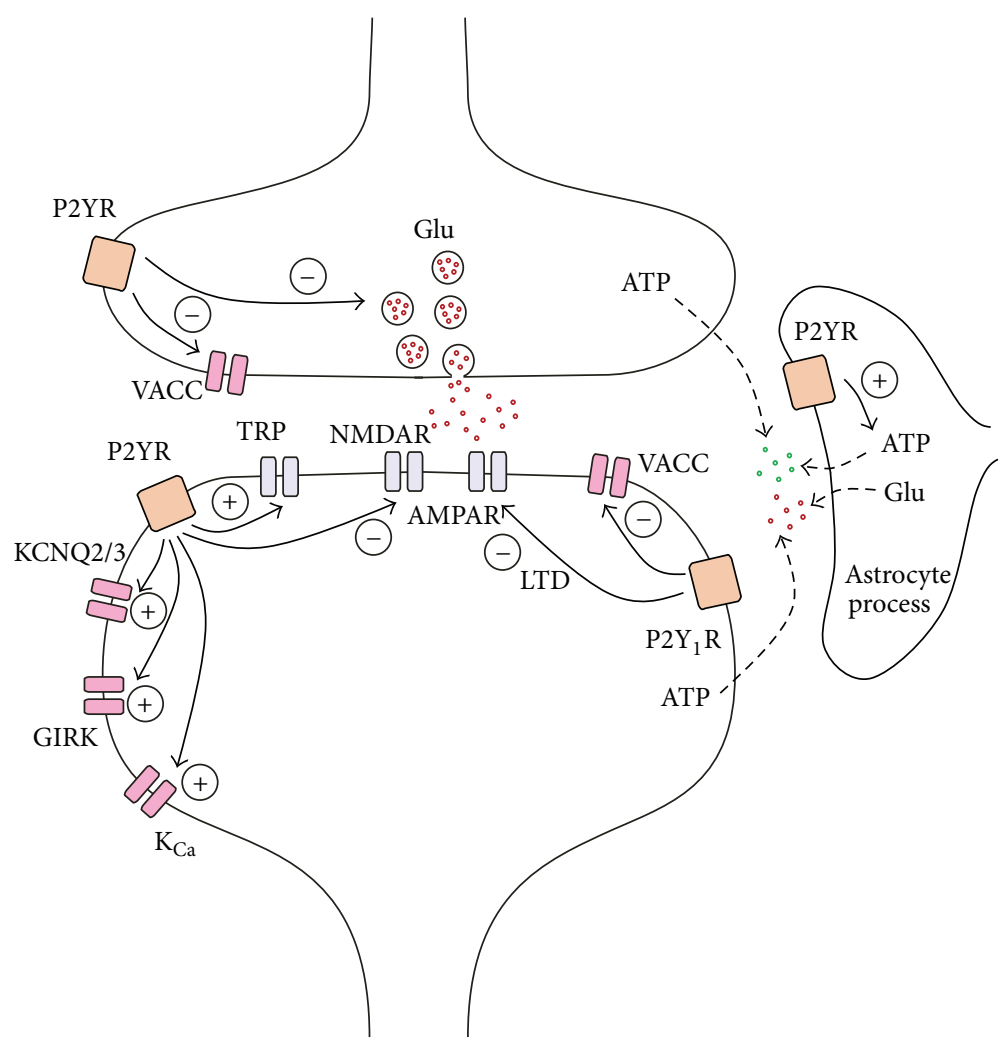

FIGURE 1: Modulation of excitatory synaptic transmission by P2Y receptors in the CNS. The model synapse shows the main presynaptic and postsynaptic effects of $\mathrm{P} 2 \mathrm{Y}$ receptors described in different areas of the brain. For more details see text. AMPAR, AMPA receptor; GIRK, G protein-coupled inwardly rectifying potassium channel; Glu, glutamate; $\mathrm{K}_{\mathrm{Ca}}$, calcium-activated potassium channel; LTD, longterm depression; NMDAR, NMDA receptor, P2YR, P2Y receptor; $\mathrm{P} 2 \mathrm{Y}_{1} \mathrm{R}, \mathrm{P} 2 \mathrm{Y}_{1}$ receptor; TRP, transient receptor potential channel; VACC, voltage-activated calcium channel.

it is hydrolyzed to adenosine in the extracellular space by ectonucleotidases [36, 37]. Although it has been suggested that ATP is involved in fast synaptic transmission in the brain via postsynaptic P2X receptors [38-41], this form of depolarization seems to be insufficient to trigger action potentials in the postsynaptic cells suggesting that the main effect of ATP is neuromodulation similar to other classical neuromodulators such as monoamines and acetylcholine [42]. In these neuromodulational effects of ATP P2Y receptors play an important role. In this review we shall overview the main effects of $\mathrm{P} 2 \mathrm{Y}$ receptors on synaptic transmission and plasticity with special emphasis on their network effects and therapeutic potentials in cognitive dysfunction.

\section{Modulation of Synaptic Transmission}

2.1. Modulation of Neurotransmitter Release. P2Y receptors have been shown to inhibit the release of a number of neurotransmitters in the CNS [43] (Figures 1 and 2). In the prefrontal cortex, $\mathrm{P}_{2} \mathrm{Y}_{1}$ receptors have been colocalized with synaptophysin and vGLUT3 suggesting that this receptor subtype is expressed in presynaptic terminals releasing glutamate [44]. $\mathrm{P}_{2} \mathrm{Y}_{1}, \mathrm{P}_{2} \mathrm{Y}_{2}, \mathrm{P}_{2} \mathrm{Y}_{4}, \mathrm{P}_{2} \mathrm{Y}_{12}$, and $\mathrm{P}_{2} \mathrm{Y}_{13}$ receptors were shown to inhibit glutamate release from the sensory terminals in the spinal cord $[45,46]$, from Schaffer collateral synapses of the hippocampus [47-49] and in the cerebral cortex [50]. Underlying this inhibitory effect is most likely a membrane delimited inhibition of $\mathrm{N}$-type voltage-activated calcium channels (VACCs) in the presynaptic terminals via the $G \beta \gamma$ subunit (see below) [45, 51]. GABA release from basket onto Purkinje cells in the cerebellum was also found to be inhibited by the activation of $\mathrm{P}_{2} \mathrm{Y}_{4}$ receptors [52]. Noradrenaline release was blocked by $\mathrm{P}_{2} \mathrm{Y}_{1}, \mathrm{P}_{2} \mathrm{Y}_{12}$, and $\mathrm{P} 2 \mathrm{Y}_{13}$ receptors in the spinal cord [46], in the hippocampus [53,54], and in the cortex [55], possibly via inhibition of VACCs [56]. Similarly, serotonin release in the cortex was decreased after $\mathrm{P} 2 \mathrm{Y}$ receptor activation [57]. The modulation of dopamine release by $\mathrm{P}_{2} \mathrm{Y}_{1}$ receptors seems to be more complex [5860]; dopaminergic terminals in the prefrontal cortex (PFC) do not contain $\mathrm{P}_{2} \mathrm{Y}_{1}$ receptors suggesting that multisynaptic mechanisms are involved [44]. In summary, presynaptically located P2Y receptors affect the release machinery of glutamate, GABA, and other neuromodulators. Although the most likely mechanism is the reduction of the release probability due to reduction of presynaptic calcium influx, alternative explanations, such alteration of the fusion machinery or other effects on the pool of vesicles, cannot be entirely discarded.

2.2. Modulation of Neurotransmitter Receptors. Activation of $\mathrm{P} 2 \mathrm{Y}$ receptors has been shown to modulate numerous 


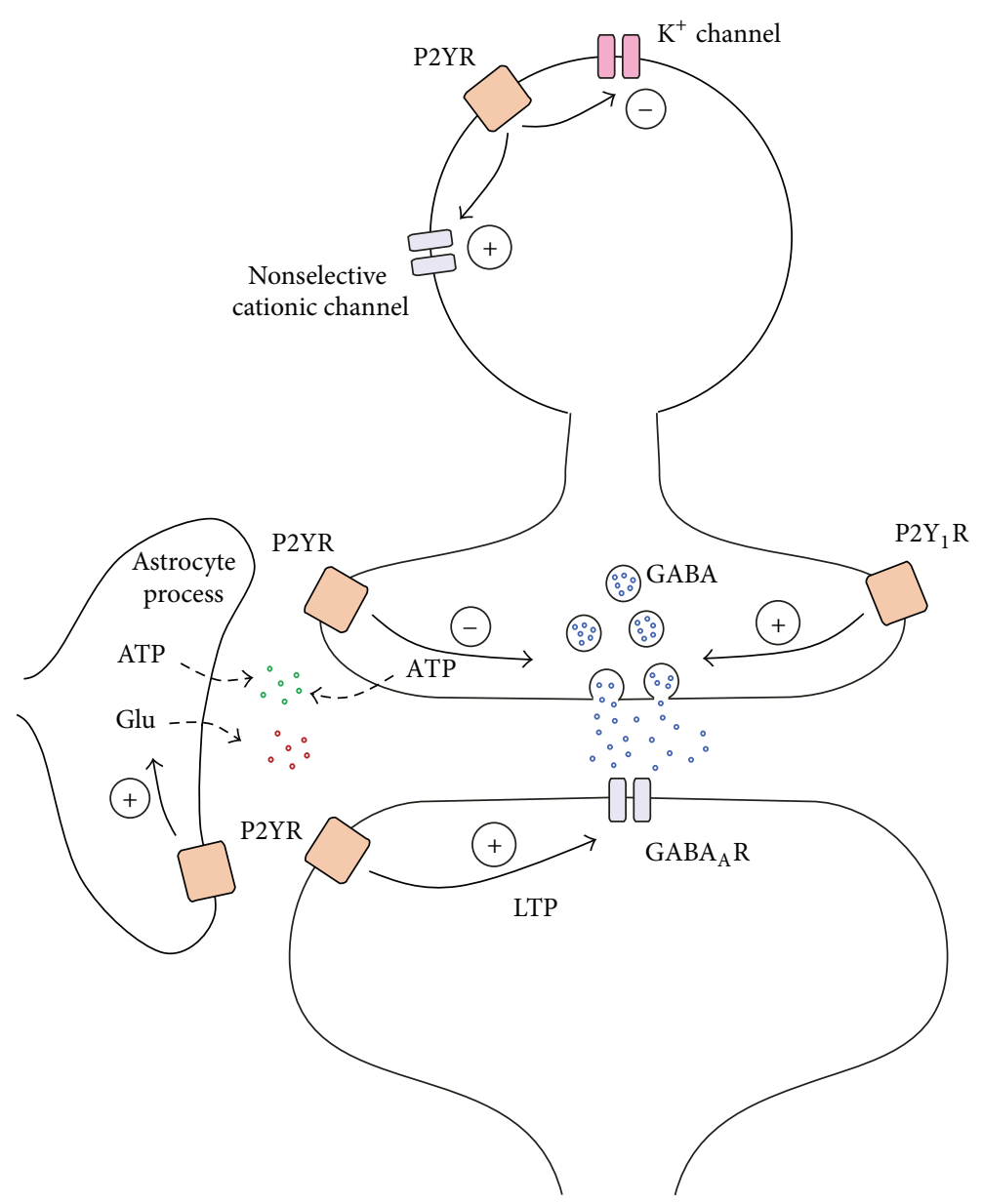

FIGURE 2: Modulation of inhibitory synaptic transmission by P2Y receptors in the CNS. The cartoon shows an idealized inhibitory (GABAergic) synapse between an inhibitory interneuron and an excitatory principal cell. The effects of P2Y receptors have been described in different brain areas. For more details see text. $\mathrm{GABA}_{\mathrm{A}} \mathrm{R}, \mathrm{GABA}_{\mathrm{A}}$ receptor; Glu, glutamate; LTP, long-term potentiation; P2YR, P2Y receptor; $\mathrm{P} 2 \mathrm{Y}_{1} \mathrm{R}, \mathrm{P} 2 \mathrm{Y}_{1}$ receptor.

membrane receptors and channels in the CNS [61] (Figures 1 and 2). Relatively few data exist demonstrating that P2Y receptors modulate other $\mathrm{G}$ protein-coupled receptors. The internalization of the metabotropic glutamate receptor 1 (mGluR1), normally triggered by glutamate, can also be triggered by activation of $\mathrm{P}_{2} \mathrm{Y}_{1}$ receptors [62].

In addition, various interactions of $\mathrm{P} 2 \mathrm{Y}$ receptors with ionotropic receptors are known. Postsynaptically located NMDA receptors were inhibited by $\mathrm{P}_{2} \mathrm{Y}_{1}$ receptor activation in layer 5 pyramidal cells of the PFC by the G $\beta \gamma$ sub-

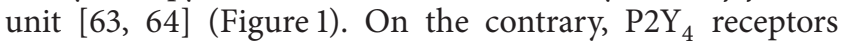
exerted positive influence on NMDA receptors. However, this effect required the release of glutamate from astrocytes via $\mathrm{P}_{2} \mathrm{Y}_{4}$ receptors, which acts on postsynaptic group I mGluRs to enhance the NMDA-mediated current [65]. The sensitivity of postsynaptic $\mathrm{GABA}_{\mathrm{A}}$ receptors in Purkinje cells was enhanced by $\mathrm{P}_{2} \mathrm{Y}_{1}$ receptor activation through a Gqmediated increase in intracellular calcium concentration [66] (Figure 2). $\mathrm{P}_{2} \mathrm{Y}_{2}$ receptors enhanced currents through $\mathrm{Ca}^{2+}$ permeable transient receptor potential vanilloid 1 (TRPV1) channels [67-69]. Although the interaction was found in the peripheral nervous system, TRPV1 are also expressed in the cerebral cortex and hippocampal pyramidal cells [70] and exert a role in synaptic plasticity [71]. P2X receptors have a $\mathrm{Ca}^{2+}$ permeability comparable to NMDA receptors $[42$, 72] that make them potential candidates for the induction of synaptic plasticity. P2X receptors were inhibited by the activation of $\mathrm{P}_{2} \mathrm{Y}_{1}$ receptors $[23,24]$.

In summary, P2Y receptors differentially influence the postsynaptic effects of neurotransmitters. Excitatory transmission mediated by postsynaptic NMDA receptors is inhibited by the activation of $\mathrm{P} 2 \mathrm{Y}$ receptors, whereas inhibitory transmission through $\mathrm{GABA}_{\mathrm{A}}$ receptors seems to be enhanced.

2.3. Modulation of Voltage-Gated Ion Channels. A typical downstream effect of $G$ protein-coupled receptors is to regulate activity of voltage-gated ion channels. P2Y receptors modulated a number of channels expressed in the CNS and that are critically involved in both synaptic transmission and plasticity $[61,73]$ (Figure 1). VACCs are a common target of P2Y receptors [74]. Almost all P2Y receptor subtypes have 
been shown to inhibit N-type VACCs [45, 51, 74-79] by the $\beta \gamma$ subunit of the $\mathrm{G}$ protein binding to the channel in a membrane delimited manner $[45,51]$. In addition, P/Qtype VACCs were inhibited by the activation of G $\beta \gamma$ [74, 80], whereas the inhibition of the L-type channels seems to involve diffusible second messengers and protein kinases activated by $\mathrm{G} \alpha$ [81-83]. N- and P/Q-type channels are involved in fast presynaptic neurotransmitter release in the CNS; L-type channels are rather localized postsynaptically and regulate dendritic signal integration, neuronal excitability, synaptic plasticity, and gene expression [84]. Thus, P2Y receptors are able to affect all these neuronal processes by interacting with different VACC subtypes (Figure 1).

Different types of potassium channels were shown to be modulated by P2Y receptors [73] (Figure 1). Voltage-gated KCNQ2/3 channels are located in the perisomatic region of pyramidal cell dendrites and are typically closed by activation of Gq-coupled receptors [85]. Almost all subtypes of P2Y receptors have been shown to inhibit KCNQ2/3 channels by activating $\mathrm{Gq}$ and intracellular $\mathrm{Ca}^{2+}$-dependent mechanisms or by $\mathrm{PIP}_{2}$ depletion [86-89]. KCNQ2/3 channels open as neurons approach the threshold for action potential. Because their activation is slow, they are not involved in the repolarization but rather in the afterhyperpolarization thus preventing burst firing of the cell [90]. Their inactivation by a $\mathrm{G}$ protein-coupled receptor such as $\mathrm{P} 2 \mathrm{Y}$ facilitates membrane excitability and may have a role in the modulation of dendritic integration.

G protein-coupled inwardly rectifying potassium (GIRK1,2,4) channels also contribute to the hyperpolarization of neurons [91] and were found to be activated by $\mathrm{P}_{2} \mathrm{Y}_{1}, \mathrm{P}_{2} \mathrm{Y}_{2}$, and $\mathrm{P} 2 \mathrm{Y}_{12}$ receptors [92-96]. Interestingly, the fast activation of the GIRK channels by $\mathrm{G} \beta \gamma$ and the subsequent hyperpolarization of the membrane were followed in case of $\mathrm{P}_{2} \mathrm{Y}_{1}$ and $\mathrm{P}_{2} \mathrm{Y}_{2}$ receptors by a slower inhibition of the channel by $\mathrm{G} \alpha$ and the subsequent activation of soluble second messengers within the following minutes $[92,95,96]$. While $\mathrm{P}_{2} \mathrm{Y}_{4}$ and $\mathrm{P} 2 \mathrm{Y}_{6}$ receptors only inhibited GIRK channels, $\mathrm{P}_{2} \mathrm{Y}_{12}$ receptors only opened them [96]. The slower inhibition is also able to reduce the activation of the channel by other GPCRs, for example, by norepinephrine. The fast activation of the potassium channel causes a stabilization of the resting membrane potential around the potassium equilibrium potential, whereas the slow inactivation is able to depolarize neurons expressing this pathway. In addition, neuronal calcium-activated potassium channels were shown to be activated by $\mathrm{P}_{2} \mathrm{Y}_{1}$ receptors. The increase in intracellular $\mathrm{Ca}^{2+}$ upon activation of $\mathrm{Gq}^{-}$ coupled P2Y receptors opens these potassium channels and hyperpolarizes the membrane [97-100].

In conclusion, depending on the subcellular expression, $\mathrm{P} 2 \mathrm{Y}$ receptors acting on voltage-gated membrane channels are able to inhibit neurotransmitter release, modulate dendritic integration, facilitate neuronal excitability, or affect other various neuronal functions such as synaptic plasticity or gene expression.

\section{Modulation of Neuronal Circuits}

A number of studies investigated the cellular and subcellular distribution of $\mathrm{P} 2 \mathrm{Y}$ receptors in the brain. In the hippocampus, $\mathrm{P}_{2} \mathrm{Y}_{1}$ receptors were located on somata and apical and basal dendrites of pyramidal cells [54, 101, 102]. Additionally, interneurons close to the pyramidal cell layer [101-103] or stratum radiatum interneurons expressing calbindin or calretinin were also stained for $\mathrm{P}_{2} \mathrm{Y}_{1}$ receptors [104]. While activation of $\mathrm{P}_{2} \mathrm{Y}_{1}$ receptors did not change the membrane potential in pyramidal cells, their activation on interneurons induced an inward nonselective cationic current likely via activating TRP channels and suppressing the $\mathrm{K}^{+}$conductance (Figure 2) $[103,104]$. This depolarized the interneuron membrane by $\sim 10 \mathrm{mV}$ and increased the firing frequency of the cells resulting in increased IPSC frequency in pyramidal neurons $[103,104]$. In the cerebral cortex, $\mathrm{P}_{2} \mathrm{Y}_{1}$ receptors were located on somata and dendrites of pyramidal cells [44, 101], on axon terminals [44], and on parvalbumin containing GABAergic cells in the PFC [44]. They were also described on stellate-like cells in the sensory-motor cortex, medial temporal cortex, and PFC [101]. P2Y receptors seem to have similar roles in the cerebellar cortex, where, together with P2X receptors, they were found to increase the activity of inhibitory basket and stellate neurons projecting onto Purkinje cells and thus decreased the main cerebellar output activity $[66,105,106]$. Therefore, it can be concluded that although purinergic $\mathrm{P} 2 \mathrm{Y}$ receptors display an excitatory effect on cell somata on the cellular level, they increase the overall inhibition in two different circuits in the brain by selectively stimulating inhibitory GABAergic interneurons [42].

Although tonic inhibition by volume release of GABA represents one form of cortical inhibition [107], the diversity of GABAergic interneurons in the cortex suggests that their role in neuronal circuits cannot be entirely assigned to a general inhibition. Rather, the role of interneuron firing has to be understood in context of the circuit to which the interneuron type contributes. Interneurons gate the information flow within a circuit and are thus important to coordinate networks [108]. Different interneuron subtypes have been described, involved in different network functions such as dendrite-targeting interneurons (modulation of synaptic efficacy and plasticity of excitatory inputs onto pyramidal cells), interneuron specific interneurons (inhibition of other interneurons), and perisomatic interneurons (synchronization of firing and generation of network oscillations) [109111]. To understand how $\mathrm{P} 2 \mathrm{Y}$ receptors affect neuronal networks, the effects of $\mathrm{P} 2 \mathrm{Y}$ receptors on identified interneuron types need to be addressed. Therefore, more information is needed in relation to which interneurons express functional purinergic receptors and how this affects the activity of the network.

The effect of $\mathrm{P} 2 \mathrm{Y}$ receptors on neuronal networks was investigated in the hippocampus [112], where $\mathrm{P}_{2} \mathrm{Y}_{1}$ receptors displayed a stimulatory effect on gamma oscillations in the CA3 area. This was likely mediated by the depolarization of parvalbumin containing perisomatic inhibitory basket cells [103] known to be responsible for the synchronization in the gamma band by rhythmic release of GABA onto pyramidal cells [113]. However, the inhibitory effect of P2X receptors on oscillations seems to be the dominating effect of endogenously released ATP [112]. On the other hand, $\mathrm{P} 2 \mathrm{Y}$ receptors play no role in epileptic network activity 
[114]. Gamma oscillations are involved in higher cognitive functions in the brain by functionally connecting neurons within a local network and between assemblies in different brain areas [115]. In addition, disturbed gamma oscillations have been observed in a line of neuropsychiatric diseases such as schizophrenia, autism spectrum disorders, and Alzheimer's disease (AD) [116, 117]. We suggest that P2 $\mathrm{Y}_{1}$ receptors, expressed on perisomatic interneurons, are in an ideal position to effectively modulate gamma oscillations and by this mechanism cognitive functions and the development of psychiatric diseases.

In conclusion, P2Y receptors are expressed postsynaptically on dendrites of pyramidal cells and possibly on glutamatergic terminals. In addition, they are present on different types of interneurons in the cortex, including the parvalbumin containing basket cells. It seems likely that, on a network level, P2Y receptors selectively excite interneurons in different cortical areas such as the hippocampus and the cerebellum. Due to the diversity of cortical and hippocampal interneuron subtypes and their physiological functions within the circuit it is of great interest to better understand the cellular distribution of purinergic receptors on different interneuron types.

Gap junctions contribute to network synchronization and are an essential part in the generation and modulation of network activity [118]. Pannexin/connexin hemichannels, on the other hand, are also involved in the release of ATP [119]. Pannexin 1 channels have been shown to be activated by $\mathrm{P} 2 \mathrm{Y}$ receptors [120] suggesting that $\mathrm{P} 2 \mathrm{Y}$ receptors are able to increase the fast electric communication between cells.

\section{Involvement in Gliotransmission}

The term tripartite synapse describes that, besides the presynaptic nerve terminal and the postsynaptic part of the neuron, processes of astrocytes also participate in the synaptic signaling by bidirectional regulation of neuronal communication [121-123]. Microglia also contact synapses and oligodendroglia have additionally been found to express receptors for neurotransmitters $[124,125]$. Astrocytes detect synaptic activity via ionotropic or metabotropic neurotransmitter receptors [126] which cause changes of astrocytic intracellular $\mathrm{Ca}^{2+}$ inducing the release of various signaling molecules, such as glutamate, ATP, and D-serine [30]. Gliotransmitters have been shown to act on neurons in a timescale of seconds to minutes to regulate synaptic transmission and plasticity. ATP has a twofold role in the bidirectional neuronglia communication. First, ATP released from neurons upon activity or during pathological conditions stimulates astrocytes by activation of $\mathrm{P}_{2} \mathrm{Y}_{1}$ receptors [123] (Figures 1 and 2). Second, ATP released from astrocytes can influence the function of neurons via activation of P2X and P2Y neuronal receptors [127] (Figures 1 and 2). Moreover, $\mathrm{P}_{2} \mathrm{Y}_{1}$ receptors on neighboring astrocytes are able to amplify the astrocyte stimulation by mediating the propagation of $\mathrm{Ca}^{2+}$ waves within the astrocytic network [128]. Bidirectional signaling between glia and neurons occurs by volume transmission $[129,130]$, and the concentration of the released transmitter drops rapidly from the release site. For that reason, receptors that are involved in neuron-glia-neuron communication, such as purinergic receptors, must have a high affinity for its agonist and a slow desensitization [122].

\section{P2Y Receptors and Synaptic Plasticity}

Several lines of evidence indicate that large amounts of ATP released under pathological conditions such as brain injury or ischemia are able to trigger synaptic plasticity by activation of P2X receptors [131-136]. This plasticity was found to be bidirectional depending on the amount and dynamics of $\mathrm{Ca}^{2+}$ influx through P2X channels [131, 132, 137]. Interestingly, ATP released under more physiological conditions is also able to modulate synaptic plasticity acting on P2X receptors. This modulation was shown to be an inhibition of longterm potentiation (LTP) via $\mathrm{Ca}^{2+}$-dependent inactivation of NMDA receptors $[138,139]$ or a facilitation of LTP in the hippocampus $[134,140]$. It has been suggested that a moderate and slow increase of intracellular $\mathrm{Ca}^{2+}$ generally induces a depression of synaptic transmission via the activation of protein phosphatases and the subsequent internalization of AMPA receptors in the membrane, whereas stronger and faster $\mathrm{Ca}^{2+}$ changes induce LTP by activation of protein kinases [136].

Aside from P2X channels, P2Y receptors were also found to have a modulatory role in synaptic plasticity. In the medial habenula nucleus, a region involved in stress, depression, and nicotine withdrawal [141], LTP of AMPA-receptor mediated currents was observed after a 5-minute application of UTP or UDP [142] via activation of presynaptic $\mathrm{P}_{2} \mathrm{Y}_{4}$ receptors.

In the cerebellum, P2X receptors have been described on Purkinje cells $[143,144]$, but ATP was not able to evoke membrane conductances suggesting the absence of functional P2X receptors $[105,106]$. On the contrary, P2Y receptor activation was shown to evoke $\mathrm{Ca}^{2+}$ transients $[66,145]$. Accordingly, activation of P2Y receptors induced LTP of the GABAergic transmission between cerebellar interneurons and Purkinje cells via $\mathrm{Ca}^{2+}$-dependent increase of $\mathrm{GABA}_{\mathrm{A}}$ receptor sensitivity [66] (Figure 2).

In the CAl area of the hippocampus, ATP released from astrocytes upon stimulation resulted in heterosynaptic long-term depression (LTD) of synapses from untetanized neighboring neurons. This was caused by the activation of presynaptic P2Y receptors and the inhibition of glutamate release [149]. Heterosynaptic LTD increases the spatial sharpness of activity-dependent induced LTP. The findings indicate that ATP release from activated astrocytes and the subsequent activation of P2Y receptors are involved in this form of plasticity.

In layer 5 pyramidal cells of the PFC, activation of P2 $\mathrm{Y}_{1}$ receptors decreased the proportion of cells that develop LTD [64] whereas blockade of $\mathrm{P}_{2} \mathrm{Y}_{1}$ receptors increased the fraction of plastic cells. In the same cells, pairing a low-frequency presynaptic stimulation with a postsynaptic depolarization induced LTD of excitatory postsynaptic currents [150] (Figure 1). The induction of LTD was dependent on the intracellular increase of calcium via mGluRls and VACCs. Activation of $\mathrm{P}_{2} \mathrm{Y}_{1}$ receptors inhibited the induction of LTD. This blockade was absent in the presence of 
TABLE 1: Pharmacological or genetic $\mathrm{P}_{2} \mathrm{Y}_{1}$ receptor intervention and cognition in animals.

\begin{tabular}{|c|c|c|c|c|c|c|c|c|}
\hline $\begin{array}{l}\text { Cognitive } \\
\text { domain }\end{array}$ & $\begin{array}{l}\text { Pathological } \\
\text { model }\end{array}$ & Drug/KO & Effect on $\mathrm{P} 2 \mathrm{Y}_{1} \mathrm{R}$ & Appl. & Species & Behavioural task & Effects & Reference \\
\hline $\begin{array}{l}\text { Aversive } \\
\text { memory }\end{array}$ & pMCAO & MRS 2500 & Antagonist & i.c.v. & Mice & $\begin{array}{c}\text { Passive } \\
\text { avoidance test }\end{array}$ & n.s. & {$[146]$} \\
\hline \multirow{2}{*}{$\begin{array}{l}\text { Fear-based } \\
\text { learning }\end{array}$} & MCAO & MRS 2500 & Antagonist & \multirow[b]{2}{*}{ i.c.v } & \multirow{2}{*}{ Mice } & $\begin{array}{l}\text { Contextual fear } \\
\text { conditioning } \\
\text { test }\end{array}$ & $\begin{array}{l}\text { Reversal of } \\
\text { deficit }\end{array}$ & {$[147]$} \\
\hline & MCAO & $\mathrm{P} 2 \mathrm{Y}_{1} \mathrm{R} \mathrm{KO}$ & Knockout & & & $\begin{array}{c}\text { Contextual fear } \\
\text { conditioning } \\
\text { test }\end{array}$ & $\begin{array}{l}\text { Reversal of } \\
\text { deficit }\end{array}$ & [147] \\
\hline $\begin{array}{l}\text { Recognition } \\
\text { memory }\end{array}$ & pMCAO & MRS 2500 & Antagonist & i.c.v. & Mice & $\begin{array}{c}\text { Object } \\
\text { recognition test }\end{array}$ & $\begin{array}{c}\text { Reversal of } \\
\text { deficit }\end{array}$ & [146] \\
\hline \multirow[b]{2}{*}{ Spatial memory } & pMCAO & MRS 2500 & Antagonist & i.c.v. & Mice & $\begin{array}{l}\text { Morris water } \\
\text { maze }\end{array}$ & $\begin{array}{c}\text { Reversal of } \\
\text { deficit }\end{array}$ & {$[146]$} \\
\hline & $\begin{array}{c}\text { Controlled } \\
\text { cortical impact } \\
\text { injury }\end{array}$ & MRS 2179 & Antagonist & i.c.v. & Mice & $\begin{array}{l}\text { Morris water } \\
\text { maze }\end{array}$ & $\begin{array}{l}\text { Reversal of } \\
\text { deficit }\end{array}$ & {$[148]$} \\
\hline \multirow{2}{*}{$\begin{array}{l}\text { Working } \\
\text { memory }\end{array}$} & \multirow{2}{*}{ pMCAO } & MRS 2500 & Antagonist & i.c.v. & Mice & Y-maze test & $\begin{array}{c}\text { Reversal of } \\
\text { deficit }\end{array}$ & {$[146]$} \\
\hline & & MRS 2365 & Agonist & $\begin{array}{l}\text { Bilateral infusion } \\
\text { into PFC }\end{array}$ & Rats & DNMTP task & Impairment & {$[44]$} \\
\hline $\begin{array}{l}\text { Reversal } \\
\text { learning }\end{array}$ & & MRS 2365 & Agonist & $\begin{array}{c}\text { Bilateral infusion } \\
\text { into PFC } \\
\end{array}$ & Rats & $\begin{array}{c}\text { Reversal } \\
\text { learning task }\end{array}$ & Impairment & {$[44]$} \\
\hline $\begin{array}{l}\text { Sensory-motor } \\
\text { gating }\end{array}$ & & MRS 2365 & Agonist & $\begin{array}{l}\text { Bilateral infusion } \\
\text { into PFC }\end{array}$ & Rats & $\begin{array}{l}\text { PPI of acoustic } \\
\text { startle response }\end{array}$ & Attenuation & {$[44]$} \\
\hline
\end{tabular}

Appl., application; DNMTP, delayed nonmatching to position; i.c.v., intracerebroventricular; KO, knockout; MCAO, middle cerebral artery occlusion; n.s., nonsignificant; $\mathrm{P} 2 \mathrm{Y}_{1} \mathrm{R}, \mathrm{P} 2 \mathrm{Y}_{1}$ receptor; PFC, prefrontal cortex; pMCAO, permanent middle cerebral artery occlusion; PPI, prepulse inhibition.

selective antagonists and in mice lacking $\mathrm{P}_{2} \mathrm{Y}_{1}$ but not $\mathrm{P} 2 \mathrm{Y}_{2}$ receptors confirming the sole involvement of $\mathrm{P}_{2} \mathrm{Y}_{1}$ receptors. $\mathrm{P} 2 \mathrm{Y}$ receptors inhibited $\mathrm{Ca}^{2+}$ transients in apical dendrites of pyramidal cells suggesting that this is the mechanism responsible for the inhibition of LTD by $\mathrm{P}_{2} \mathrm{Y}_{1}$ receptors. In addition, ATP, released under hypoxia, was found to inhibit LTD. This effect was mediated by $\mathrm{P}_{2} \mathrm{Y}_{1}$ receptors because application of a $\mathrm{P}_{2} \mathrm{Y}_{1}$ receptor antagonist during hypoxia allowed the induction of LTD [150].

These data suggest that effects of P2Y receptors on synaptic plasticity in the hippocampus and cerebellar cortex are different than those found in the PFC. While the effect of $\mathrm{P} 2 \mathrm{Y}$ receptors in the hippocampus and cerebellar cortex was to develop both LTP and heterosynaptic LTD, the activation of $\mathrm{P}_{2} \mathrm{Y}_{1}$ receptors caused an inhibition of LTD in the PFC.

\section{Pathophysiological Role of Central P2Y Receptors}

Among P2Y receptors, $\mathrm{P}_{2} \mathrm{Y}_{1}$ receptors were suggested as one of the predominant targets of ATP in mediating danger signals in the brain during, for example, ischemia [22, 146, 151] or trauma $[148,152]$. One of the main roles of $\mathrm{P}_{2} \mathrm{Y}_{1}$ receptors under pathological circumstances is the modulation of astrocytic networks by mediation of $\mathrm{Ca}^{2+}$ waves and activation of astrocytes upon mechanical injury [153], ischemia [154], or $\mathrm{AD}$ [155]. The $\mathrm{Ca}^{2+}$ waves evoked by mechanical trauma depressed the activity of neural circuits after mechanical injury [148]. Blockade or deletion of the $\mathrm{P}_{2} \mathrm{Y}_{1}$ receptors was shown to reduce the infarct volume [22] and cell death in the hippocampus [148] suggesting the mediatory role of the receptor in these processes. $\mathrm{P}_{2} \mathrm{Y}_{1}$ receptors were found to colocalize with neurofibrillary tangles and amyloid $\beta(\mathrm{A} \beta)$ plaques characteristic to $\mathrm{AD}$ [156] and reactive astrocytes near $A \beta$ plaques showed enhanced $\mathrm{P}_{2} \mathrm{Y}_{1}$ receptor mediated $\mathrm{Ca}^{2+}$ signaling [155]. The astrocytic hyperactivity could be blocked by inhibiting the release of ATP or by pharmacological antagonism of $\mathrm{P}_{2} \mathrm{Y}_{1}$ receptors. This suggests that substances that prevent the effect of ATP on $\mathrm{P}_{2} \mathrm{Y}_{1}$ receptors could be used as therapeutic tools for the treatment of $\mathrm{AD}[157,158]$.

On the contrary, activation of other $\mathrm{P} 2 \mathrm{Y}$ receptors was described to have neuroprotective effects in neuroinflammatory processes such as $\mathrm{AD}$ [158]. While activation of the $\mathrm{P}_{2} \mathrm{Y}_{2}$ receptors stimulated neurite outgrow and nonamyloidogenic processing of amyloid precursor protein [159] as well as uptake of $A \beta[160]$, knockdown of the receptors was shown

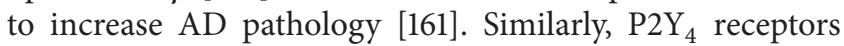
present on microglia were also found to play a role in the uptake of $\mathrm{A} \beta$ [162] and $\mathrm{P}_{2} \mathrm{Y}_{12}$ receptors were described to stimulate microglial migration towards neuronal damage [163]. Finally, activation of $\mathrm{P}_{2} \mathrm{Y}_{13}$ receptors on rat primary cerebellar neurons was shown to protect against oxidative stress-induced neuronal death [164].

Emerging evidence indicates that $\mathrm{P}_{2} \mathrm{Y}_{1}$ receptors are involved in the development of cognitive deficits after traumatic brain injury or focal cerebral stroke (Table 1). Antagonism 
of $\mathrm{P}_{2} \mathrm{Y}_{1}$ receptors improved cognitive deficits after controlled cortical impact brain injury [148]. Short (45 min) middle cerebral artery occlusion (MCAO) caused longlasting sensory-motor and cognitive deficits in mice and rats [147]. While the neurological deficits recovered within weeks, cognitive deficits persisted for long time representing the main clinical problem after ischemia. In $\mathrm{P}_{2} \mathrm{Y}_{1}$ knockout mice and after antagonism of $\mathrm{P}_{2} \mathrm{Y}_{1}$ receptors, the cognitive decline after MCAO completely failed, whereas the transient sensorymotor symptoms were still present [147]. Similarly, permanent MCAO induced neuronal damage, astrogliosis, and microgliosis and decreased working and reference memory performances [146]. $\mathrm{P}_{2} \mathrm{Y}_{1}$ receptor antagonism attenuated the neuronal damage and the cognitive performance without inhibiting the astrocytic or microglial reactivity upon brain injury [146] suggesting that neuronal mechanisms are predominantly involved in the neuroprotective effects of $\mathrm{P}_{2} \mathrm{Y}_{1}$ receptor antagonism. Application of a selective $\mathrm{P}_{2} \mathrm{Y}_{1}$ receptor agonist into the medial PFC impaired cognitive performances in working memory and learning tasks [44]. In the same study, stimulation of $\mathrm{P}_{2} \mathrm{Y}_{1}$ receptors was found to attenuate prepulse inhibition of the acoustic startle reflex without affecting the startle response amplitude [44]. Deficits of prepulse inhibition indicate the reduced capability to filter out unnecessary information that is observed in schizophrenic patients [147].

All together, we suggest that the procognitive and neuroprotective effects provided by $\mathrm{P}_{2} \mathrm{Y}_{1}$ receptor antagonists may have two components. First, the reduction of glial cell activation may inhibit the network depressing effect of astrocytic calcium waves. Second, the modulation of neuronal communication might influence synaptic transmission, plasticity, and network activity such as neuronal oscillations. The presented data indicate that $\mathrm{P} 2 \mathrm{Y}$ receptors, particularly $\mathrm{P}_{2} \mathrm{Y}_{1}$ receptors, are emerging targets for the treatment of pathological processes that involve cognitive dysfunction. Antagonists of the $\mathrm{P}_{2} \mathrm{Y}_{1}$ receptor may protect against cognitive impairments after brain injury and have nootropic effects. In contrast, activation of $\mathrm{P}_{2} \mathrm{Y}_{2}, \mathrm{P}_{2} \mathrm{Y}_{4}, \mathrm{P}_{2} \mathrm{Y}_{12}$, and $\mathrm{P}_{2} \mathrm{Y}_{13}$ receptors may have a protective effect and might be beneficial in the treatment of neurodegenerative diseases.

\section{Conclusion}

P2Y receptors are activated by ATP released from astrocytes and neurons upon increased neuronal activity or under pathophysiological conditions. They are able to modulate synaptic transmission and plasticity by interactions with voltage-activated calcium and potassium channels, as well as ionotropic receptors. In the hippocampus and the cerebellar cortex, P2Y receptors activate inhibitory GABAergic interneurons playing a key role in timing and organization of principal cell firing. The modulatory effects of $\mathrm{P} 2 \mathrm{Y}$ receptors on membrane channels and receptors are sufficient to influence synaptic transmission and plasticity which may sustainably affect the connectivity between different excitatory and inhibitory cell types and thus the network activity in different brain areas. Therefore, P2Y receptors represent important pharmacological targets to treat cognitive dysfunctions and neuropsychiatric diseases, such as Alzheimer's disease and schizophrenia.

\section{Conflict of Interests}

The authors declare that there is no conflict of interests regarding the publication of this paper.

\section{References}

[1] C. H. Fiske and Y. SubbaRow, "Phosphorus compounds of muscle and liver," Science, vol. 70, no. 1816, pp. 381-382, 1929.

[2] K. Lohman, "Über die Pyrophosphatfraktion im Muskel," Naturwissenschaften, vol. 17, pp. 624-625, 1929.

[3] A. N. Drury and A. Szent-Györgyi, "The physiological activity of adenine compounds with especial reference to their action upon the mammalian heart," The Journal of Physiology, vol. 68, no. 3, pp. 213-237, 1929.

[4] G. Burnstock, "Historical review: ATP as a neurotransmitter," Trends in Pharmacological Sciences, vol. 27, no. 3, pp. 166-176, 2006.

[5] G. Burnstock, "Purinergic nerves," Pharmacological Reviews, vol. 24, no. 3, pp. 509-581, 1972.

[6] G. Burnstock, "Purinergic receptors," Journal of Theoretical Biology, vol. 62, no. 2, pp. 491-503, 1976.

[7] G. Burnstock and C. Kennedy, "Is there a basis for distinguishing two types of P2-purinoceptor?" General Pharmacology, vol. 16, no. 5, pp. 433-440, 1985.

[8] H. A. Kolb and M. J. O. Wakelam, "Transmitter-like action of ATP on patched membranes of cultured myoblasts and myotubes," Nature, vol. 303, no. 5918, pp. 621-623, 1983.

[9] C. D. Benham and R. W. Tsien, "A novel receptor-operated Ca ${ }^{2+}$ permeable channel activated by ATP in smooth muscle," Nature, vol. 328, no. 6127, pp. 275-278, 1987.

[10] R. Charest, P. F. Blackmore, and J. H. Exton, "Characterization of responses of isolated rat hepatocytes to ATP and ADP," The Journal of Biological Chemistry, vol. 260, no. 29, pp. 15789-15794, 1985.

[11] J. L. Boyer, G. L. Waldo, T. Evans, J. K. Northup, C. P. Downes, and T. K. Harden, "Modification of AlF-4- and receptorstimulated phospholipase C activity by G-protein beta gamma subunits," The Journal of Biological Chemistry, vol. 264, no. 23, pp. 13917-13922, 1989.

[12] I. von Kügelgen and K. Hoffmann, "Pharmacology and structure of P2Y receptors," Neuropharmacology, 2015.

[13] M. P. Abbracchio, G. Burnstock, J.-M. Boeynaems et al., "International Union of Pharmacology LVIII: update on the P2Y G protein-coupled nucleotide receptors: from molecular mechanisms and pathophysiology to therapy," Pharmacological Reviews, vol. 58, no. 3, pp. 281-341, 2006.

[14] L. Erb, Z. Liao, C. I. Seye, and G. A. Weisman, "P2 receptors: intracellular signaling," Pflügers Archiv, vol. 452, no. 5, pp. 552$562,2006$.

[15] T. D. Nguyen, S. Meichle, U. S. Kim, T. Wong, and M. W. Moody, "P2 $\mathrm{Y}_{11}$, a purinergic receptor acting via cAMP, mediates secretion by pancreatic duct epithelial cells," The American Journal of Physiology-Gastrointestinal and Liver Physiology, vol. 280, no. 5, pp. G795-G804, 2001.

[16] G. Burnstock and G. E. Knight, "Cellular distribution and functions of $\mathrm{P} 2$ receptor subtypes in different systems," International Review of Cytology, vol. 240, pp. 31-304, 2004. 
[17] P. B. Guthrie, J. Knappenberger, M. Segal, M. V. L. Bennett, A. C. Charles, and S. B. Kater, "ATP released from astrocytes mediates glial calcium waves," The Journal of Neuroscience, vol. 19, no. 2, pp. 520-528, 1999.

[18] R. D. Fields and G. Burnstock, "Purinergic signalling in neuronglia interactions," Nature Reviews Neuroscience, vol. 7, no. 6, pp. 423-436, 2006.

[19] S. K. Mishra, N. Braun, V. Shukla et al., "Extracellular nucleotide signaling in adult neural stem cells: synergism with growth factor-mediated cellular proliferation," Development, vol. 133, no. 4, pp. 675-684, 2006.

[20] G. A. Weisman, L. T. Woods, L. Erb, and C. I. Seye, "P2Y receptors in the mammalian nervous system: pharmacology, ligands and therapeutic potential," CNS \& Neurological DisordersDrug Targets, vol. 11, no. 6, pp. 722-738, 2012.

[21] H. Franke and P. Illes, "Involvement of P2 receptors in the growth and survival of neurons in the CNS," Pharmacology and Therapeutics, vol. 109, no. 3, pp. 297-324, 2006.

[22] K. Kuboyama, H. Harada, H. Tozaki-Saitoh, M. Tsuda, K. Ushijima, and $\mathrm{K}$. Inoue, "Astrocytic $\mathrm{P}_{2} \mathrm{Y}_{1}$ receptor is involved in the regulation of cytokine/chemokine transcription and cerebral damage in a rat model of cerebral ischemia," Journal of Cerebral Blood Flow and Metabolism, vol. 31, no. 9, pp. 19301941, 2011.

[23] Z. Gerevich, C. Müller, and P. Illes, "Metabotropic P2Y1 receptors inhibit $\mathrm{P} 2 \mathrm{X} 3$ receptor-channels in rat dorsal root ganglion neurons," European Journal of Pharmacology, vol. 521, no. 1-3, pp. 34-38, 2005.

[24] Z. Gerevich, Z. Zadori, C. Müller et al., "Metabotropic $\mathrm{P} 2 \mathrm{Y}$ receptors inhibit $\mathrm{P} 2 \mathrm{X} 3$ receptor-channels via G proteindependent facilitation of their desensitization," British Journal of Pharmacology, vol. 151, no. 2, pp. 226-236, 2007.

[25] Z. Gerevich and P. Illes, "P2Y receptors and pain transmission," Purinergic Signalling, vol. 1, no. 1, pp. 3-10, 2004.

[26] G. Burnstock and A. Verkhratsky, "Long-term (trophic) purinergic signalling: purinoceptors control cell proliferation, differentiation and death," Cell Death and Disease, vol. 1, article e9, 2010.

[27] M. Idzko, D. Ferrari, and H. K. Eltzschig, "Nucleotide signalling during inflammation,” Nature, vol. 509, no. 7500, pp. 310-317, 2014.

[28] Y. Pankratov, U. Lalo, A. Verkhratsky, and R. A. North, "Vesicular release of ATP at central synapses," Pflügers Archiv, vol. 452, no. 5, pp. 589-597, 2006.

[29] R. D. Fields, "Nonsynaptic and nonvesicular ATP release from neurons and relevance to neuron-glia signaling," Seminars in Cell and Developmental Biology, vol. 22, no. 2, pp. 214-219, 2011.

[30] P. Bezzi and A. Volterra, "A neuron-glia signalling network in the active brain," Current Opinion in Neurobiology, vol. 11, no. 3, pp. 387-394, 2001.

[31] Y. Imura, Y. Morizawa, R. Komatsu et al., "Microglia release ATP by exocytosis," Glia, vol. 61, no. 8, pp. 1320-1330, 2013.

[32] J. George, F. Q. Gonçalves, G. Cristóvão et al., "Different danger signals differently impact on microglial proliferation through alterations of ATP release and extracellular metabolism," Glia, vol. 63, no. 9, pp. 1636-1645, 2015.

[33] A. Bal-Price, Z. Moneer, and G. C. Brown, "Nitric oxide induces rapid, calcium-dependent release of vesicular glutamate and ATP from cultured rat astrocytes," Glia, vol. 40, no. 3, pp. 312$323,2002$.
[34] T. D. Montero and J. A. Orellana, "Hemichannels: new pathways for gliotransmitter release," Neuroscience, vol. 286, pp. 45-59, 2015.

[35] S. Duan, C. M. Anderson, E. C. Keung, Y. Chen, Y. Chen, and R. A. Swanson, "P2X7 receptor-mediated release of excitatory amino acids from astrocytes," Journal of Neuroscience, vol. 23, no. 4, pp. 1320-1328, 2003.

[36] T. V. Dunwiddie, L. Diao, and W. R. Proctor, "Adenine nucleotides undergo rapid, quantitative conversion to adenosine in the extracellular space in rat hippocampus," Journal of Neuroscience, vol. 17, no. 20, pp. 7673-7682, 1997.

[37] H. Zimmermann, "Ectonucleotidases in the nervous system," Novartis Foundation Symposium, vol. 276, pp. 113-128, 2006.

[38] F. A. Edwards, A. J. Gibb, and D. Colquhoun, "ATP receptormediated synaptic currents in the central nervous system," Nature, vol. 359, no. 6391, pp. 144-147, 1992.

[39] R. J. Evans, V. Derkach, and A. Surprenant, "ATP mediates fast synaptic transmission in mammalian neurons," Nature, vol. 357, no. 6378, pp. 503-505, 1992.

[40] E. M. Silinsky, V. Gerzanich, and S. M. Vanner, "ATP mediates excitatory synaptic transmission in mammalian neurones," British Journal of Pharmacology, vol. 106, no. 4, pp. 762-763, 1992.

[41] Y. Pankratov, E. Castro, M. T. Miras-Portugal, and O. Krishtal, "A purinergic component of the excitatory postsynaptic current mediated by $\mathrm{P} 2 \mathrm{X}$ receptors in the CA1 neurons of the rat hippocampus," European Journal of Neuroscience, vol. 10, no. 12, pp. 3898-3902, 1998.

[42] B. S. Khakh and R. A. North, "Neuromodulation by extracellular ATP and P2X Receptors in the CNS," Neuron, vol. 76, no. 1, pp. 51-69, 2012.

[43] B. Sperlágh, A. Heinrich, and C. Csöllle, "P2 receptor-mediated modulation of neurotransmitter release-an update," Purinergic Signalling, vol. 3, no. 4, pp. 269-284, 2007.

[44] H. Koch, A. Bespalov, K. Drescher, H. Franke, and U. Krügel, "Impaired cognition after stimulation of P2Y1 receptors in the rat medial prefrontal cortex," Neuropsychopharmacology, vol. 40, pp. 305-314, 2015.

[45] Z. Gerevich, S. J. Borvendeg, W. Schröder et al., "Inhibition of $\mathrm{N}$-type voltage-activated calcium channels in rat dorsal root ganglion neurons by $\mathrm{P} 2 \mathrm{Y}$ receptors is a possible mechanism of ADP-induced analgesia," Journal of Neuroscience, vol. 24, no. 4, pp. 797-807, 2004.

[46] A. Heinrich, Á. Kittel, C. Csölle, E. Sylvester Vizi, and B. Sperlágh, "Modulation of neurotransmitter release by P2X and P2Y receptors in the rat spinal cord," Neuropharmacology, vol. 54, no. 2, pp. 375-386, 2008.

[47] V. Mendoza-Fernandez, R. D. Andrew, and C. Barajas-López, "ATP inhibits glutamate synaptic release by acting at P2Y receptors in pyramidal neurons of hippocampal slices," Journal of Pharmacology and Experimental Therapeutics, vol. 293, no. 1, pp. 172-179, 2000.

[48] R. J. Rodrigues, T. Almeida, P. J. Richardson, C. R. Oliveira, and R. A. Cunha, "Dual presynaptic control by ATP of glutamate release via facilitatory $\mathrm{P} 2 \mathrm{X} 1, \mathrm{P} 2 \mathrm{X} 2 / 3$, and $\mathrm{P} 2 \mathrm{X} 3$ and inhibitory $\mathrm{P} 2 \mathrm{Y} 1, \mathrm{P} 2 \mathrm{Y} 2$, and/or P2Y4 receptors in the rat hippocampus," Journal of Neuroscience, vol. 25, no. 27, pp. 6286-6295, 2005.

[49] S. Koizumi, K. Fujishita, M. Tsuda, Y. Shigemoto-Mogami, and K. Inoue, "Dynamic inhibition of excitatory synaptic transmission by astrocyte-derived ATP in hippocampal cultures," Proceedings of the National Academy of Sciences of the United States of America, vol. 100, no. 19, pp. 11023-11028, 2003. 
[50] G. C. Bennett and M. R. Boarder, "The effect of nucleotides and adenosine on stimulus-evoked glutamate release from rat brain cortical slices," British Journal of Pharmacology, vol. 131, no. 3, pp. 617-623, 2000.

[51] A. K. Filippov, T. E. Webb, E. A. Barnard, and D. A. Brown, "Inhibition by heterologously-expressed P2Y2 nucleotide receptors of N-type calcium currents in rat sympathetic neurones," British Journal of Pharmacology, vol. 121, no. 5, pp. 849-851, 1997.

[52] R. Donato, R. J. Rodrigues, M. Takahashi et al., "GABA release by basket cells onto Purkinje cells, in rat cerebellar slices, is directly controlled by presynaptic purinergic receptors, modulating $\mathrm{Ca}^{2+}$ influx," Cell Calcium, vol. 44, no. 6, pp. 521-532, 2008.

[53] H. Koch, I. von Kügelgen, and K. Starke, "P2-receptor-mediated inhibition of noradrenaline release in the rat hippocampus," Naunyn-Schmiedeberg's Archives of Pharmacology, vol. 355, no. 6, pp. 707-715, 1997.

[54] C. Csölle, A. Heinrich, Á. Kittel, and B. Sperlágh, "P2Y receptor mediated inhibitory modulation of noradrenaline release in response to electrical field stimulation and ischemic conditions in superfused rat hippocampus slices," Journal of Neurochemistry, vol. 106, no. 1, pp. 347-360, 2008.

[55] I. von Kügelgen, K. Kurz, and K. Starke, "P2-purinoceptormediated autoinhibition of sympathetic transmitter release in mouse and rat vas deferens," Naunyn-Schmiedeberg's Archives of Pharmacology, vol. 349, no. 2, pp. 125-132, 1994.

[56] S. G. Lechner, M. M. Dorostkar, M. Mayer, H. Edelbauer, H. Pankevych, and S. Boehm, "Autoinhibition of transmitter release from PC12 cells and sympathetic neurons through a P2 $\mathrm{Y}_{12}$ receptor-mediated inhibition of voltage-gated $\mathrm{Ca}^{2+}$ channels," European Journal of Neuroscience, vol. 20, no. 11, pp. 29172928, 2004.

[57] I. von Kügelgen, H. Koch, and K. Starke, "P2-receptor-mediated inhibition of serotonin release in the rat brain cortex," $\mathrm{Neu}$ ropharmacology, vol. 36, no. 9, pp. 1221-1227, 1997.

[58] Y.-X. Zhang, H. Yamashita, T. Ohshita, N. Sawamoto, and S. Nakamura, "ATP increases extracellular dopamine level through stimulation of P2Y purinoceptors in the rat striatum," Brain Research, vol. 691, no. 1-2, pp. 205-212, 1995.

[59] A. U. Trendelenburg and R. Bültmann, "P2 receptor-mediated inhibition of dopamine release in rat neostriatum," Neuroscience, vol. 96, no. 2, pp. 249-252, 2000.

[60] U. Krügel, H. Kittner, H. Franke, and P. Illes, "Stimulation of P2 receptors in the ventral tegmental area enhances dopaminergic mechanisms in vivo," Neuropharmacology, vol. 40, no. 8, pp. 1084-1093, 2001.

[61] L. Köles, Z. Gerevich, J. F. Oliveira, Z. S. Zadori, K. Wirkner, and P. Illes, "Interaction of $\mathrm{P} 2$ purinergic receptors with cellular macromolecules," Naunyn-Schmiedeberg's Archives of Pharmacology, vol. 377, no. 1, pp. 1-33, 2008.

[62] S. J. Mundell, G. Pula, R. A. J. McIlhinney, P. J. Roberts, and E. Kelly, "Desensitization and internalization of metabotropic glutamate receptor 1a following activation of heterologous Gq/11coupled receptors," Biochemistry, vol. 43, no. 23, pp. 7541-7551, 2004.

[63] J. Luthardt, S. J. Borvendeg, B. Sperlagh, W. Poelchen, K. Wirkner, and $\mathrm{P}$. Illes, "P2Y $\mathrm{Y}_{1}$ receptor activation inhibits NMDA receptor-channels in layer $\mathrm{V}$ pyramidal neurons of the rat prefrontal and parietal cortex," Neurochemistry International, vol. 42, no. 2, pp. 161-172, 2003.
[64] S. J. Guzman, Z. Gerevich, J. G. Hengstler, P. Illes, and W. Kleemann, "P2Y1 receptors inhibit both strength and plasticity of glutamatergic synaptic neurotransmission in the rat prefrontal cortex," Synapse, vol. 57, no. 4, pp. 235-238, 2005.

[65] K. Wirkner, A. Günther, M. Weber et al., "Modulation of NMDA receptor current in layer V pyramidal neurons of the rat prefrontal cortex by $\mathrm{P} 2 \mathrm{Y}$ receptor activation," Cerebral Cortex, vol. 17, no. 3, pp. 621-631, 2007.

[66] F. Saitow, T. Murakoshi, H. Suzuki, and S. Konishi, "Metabotropic P2Y purinoceptor-mediated presynaptic and postsynaptic enhancement of cerebellar GABAergic transmission," Journal of Neuroscience, vol. 25, no. 8, pp. 2108-2116, 2005.

[67] M. Tominaga, M. Wada, and M. Masu, "Potentiation of capsaicin receptor activity by metabotropic ATP receptors as a possible mechanism for ATP-evoked pain and hyperalgesia," Proceedings of the National Academy of Sciences of the United States of America, vol. 98, no. 12, pp. 6951-6956, 2001.

[68] T. Moriyama, T. Iida, K. Kobayashi et al., "Possible involvement of P2Y2 metabotropic receptors in ATP-induced transient receptor potential vanilloid receptor 1-mediated thermal hypersensitivity," Journal of Neuroscience, vol. 23, no. 14, pp. 60586062, 2003.

[69] S. Lakshmi and P. G. Joshi, "Co-activation of P2Y2 receptor and TRPV channel by ATP: implications for ATP induced pain," Cellular and Molecular Neurobiology, vol. 25, no. 5, pp. 819-832, 2005.

[70] J. A. Kauer and H. E. Gibson, "Hot flash: TRPV channels in the brain," Trends in Neurosciences, vol. 32, no. 4, pp. 215-224, 2009.

[71] H. E. Gibson, J. G. Edwards, R. S. Page, M. J. Van Hook, and J. A. Kauer, "TRPV1 channels mediate long-term depression at synapses on hippocampal interneurons," Neuron, vol. 57, no. 5, pp. 746-759, 2008.

[72] P. Paoletti, C. Bellone, and Q. Zhou, "NMDA receptor subunit diversity: impact on receptor properties, synaptic plasticity and disease," Nature Reviews Neuroscience, vol. 14, no. 6, pp. 383400, 2013.

[73] S. G. Lechner and S. Boehm, "Regulation of neuronal ion channels via P2Y receptors," Purinergic Signalling, vol. 1, no. 1, pp. 31-41, 2004.

[74] M. Dlverse-Plerluissi, K. Dunlap, and E. W. Westhead, "Multiple actions of extracellular ATP on calcium currents in cultured bovine chromaffin cells," Proceedings of the National Academy of Sciences of the United States of America, vol. 88, no. 4, pp. 1261$1265,1991$.

[75] A. K. Filippov, T. E. Webb, E. A. Barnard, and D. A. Brown, "Dual coupling of heterologously-expressed rat $\mathrm{P} 2 \mathrm{Y}_{6}$ nucleotide receptors to $\mathrm{N}$-type $\mathrm{Ca}^{2+}$ and $\mathrm{M}$-type $\mathrm{K}^{+}$currents in rat sympathetic neurones," British Journal of Pharmacology, vol. 126, no. 4, pp. 1009-1017, 1999.

[76] A. K. Filippov, D. A. Brown, and E. A. Barnard, “The P2Y receptor closes the $\mathrm{N}$-type $\mathrm{Ca}^{2+}$ channel in neurones, with both adenosine triphosphates and diphosphates as potent agonists," British Journal of Pharmacology, vol. 129, no. 6, pp. 1063-1066, 2000.

[77] A. K. Filippov, J. Simon, E. A. Barnard, and D. A. Brown, "Coupling of the nucleotide $\mathrm{P}_{2} \mathrm{Y}_{4}$ receptor to neuronal ion channels," British Journal of Pharmacology, vol. 138, no. 2, pp. 400-406, 2003.

[78] K. Wirkner, J. Schweigel, Z. Gerevich et al., "Adenine nucleotides inhibit recombinant $\mathrm{N}$-type calcium channels via G protein-coupled mechanisms in HEK 293 cells; involvement 
of the P2Y 13 receptor-type," British Journal of Pharmacology, vol. 141, no. 1, pp. 141-151, 2004.

[79] S. J. Borvendeg, Z. Gerevich, C. Gillen, and P. Illes, "P2Y receptor-mediated inhibition of voltage-dependent $\mathrm{Ca}^{2+}$ channels in rat dorsal root ganglion neurons," Synapse, vol. 47, no. 2, pp. 159-161, 2003.

[80] M. Abe, T. Endoh, and T. Suzuki, "Extracellular ATP-induced calcium channel inhibition mediated by P1/P2Y purinoceptors in hamster submandibular ganglion neurons," British Journal of Pharmacology, vol. 138, no. 8, pp. 1535-1543, 2003.

[81] Y. Qu, D. L. Campbell, and H. C. Strauss, "Modulation of L-type $\mathrm{Ca}^{2+}$ current by extracellular ATP in ferret isolated right ventricular myocytes," Journal of Physiology, vol. 471, pp. 295-317, 1993.

[82] Q. Gong, M. Kakei, N. Koriyama et al., "P2Y-purinoceptor mediated inhibition of L-type $\mathrm{Ca}^{2+}$ channels in rat pancreatic $\beta$-cells," Cell Structure and Function, vol. 25, no. 5, pp. 279-289, 2000.

[83] K. P. Monaghan, D. K. Sang, S. Ro, J. Yeom, B. Horowitz, and K. M. Sanders, "Nucleotide regulation of the voltage-dependent nonselective cation conductance in murine colonic myocytes," American Journal of Physiology - Cell Physiology, vol. 291, no. 5, pp. C985-C994, 2006.

[84] B. A. Simms and G. W. Zamponi, "Neuronal voltage-gated calcium channels: structure, function, and dysfunction," Neuron, vol. 82, no. 1, pp. 24-45, 2014.

[85] G. A. Gutman, K. G. Chandy, S. Grissmer et al., "International Union of Pharmacology. LIII. Nomenclature and molecular relationships of voltage-gated potassium channels," Pharmacological Reviews, vol. 57, no. 4, pp. 473-508, 2005.

[86] H. S. Lopez and P. R. Adams, "A G protein mediates the inhibition of the voltage-dependent potassium $\mathrm{M}$ current by muscarine, LHRH, substance P and UTP in bullfrog sympathetic neurons," European Journal of Neuroscience, vol. 1, no. 5, pp. 529-542, 1989.

[87] K. Nakazawa, K. Inoue, and K. Inoue, "ATP reduces voltageactivated $\mathrm{K}^{+}$current in cultured rat hippocampal neurons," Pflugers Archiv, vol. 429, no. 1, pp. 143-145, 1994.

[88] S. Boehm, "Selective inhibition of M-type potassium channels in rat sympathetic neurons by uridine nucleotide preferring receptors," British Journal of Pharmacology, vol. 124, no. 6, pp. 1261-1269, 1998.

[89] A. K. Filippov, R. C. Y. Choi, J. Simon, E. A. Barnard, and D. A. Brown, "Activation of $\mathrm{P}_{2} \mathrm{Y}_{1}$ nucleotide receptors induces inhibition of the M-type $\mathrm{K}^{+}$current in rat hippocampal pyramidal neurons," Journal of Neuroscience, vol. 26, no. 36, pp. 9340-9348, 2006.

[90] D. A. Brown and G. M. Passmore, "Neural KCNQ (Kv7) channels," British Journal of Pharmacology, vol. 156, no. 8, pp. 1185-1195, 2009.

[91] C. Lüscher and P. A. Slesinger, "Emerging roles for G proteingated inwardly rectifying potassium (GIRK) channels in health and disease," Nature Reviews Neuroscience, vol. 11, no. 5, pp. 301315, 2010.

[92] H. Matsuura and T. Ehara, "Modulation of the muscarinic $\mathrm{K}^{+}$ channel by $\mathrm{P} 2$-purinoceptors in guinea-pig atrial myocytes," Journal of Physiology, vol. 497, no. 2, pp. 379-393, 1996.

[93] M. D. Mark, J. P. Ruppersberg, and S. Herlitze, "Regulation of GIRK channel deactivation by $\mathrm{G} \alpha(\mathrm{q})$ and $\mathrm{G} \alpha(\mathrm{i} / \mathrm{o})$ pathways," Neuropharmacology, vol. 39, no. 12, pp. 2360-2373, 2000.
[94] G. Hollopeter, H.-M. Jantzen, D. Vincent et al., "Identification of the platelet ADP receptor targeted by antithrombotic drugs," Nature, vol. 409, no. 6817, pp. 202-207, 2001.

[95] J. Simon, A. K. Filippov, S. Göransson et al., "Characterization and channel coupling of the P2Y12 nucleotide receptor of brain capillary endothelial cells," The Journal of Biological Chemistry, vol. 277, no. 35, pp. 31390-31400, 2002.

[96] A. K. Filippov, J. M. Fernández-Fernández, S. J. Marsh, J. Simon, E. A. Barnard, and D. A. Brown, "Activation and inhibition of neuronal $\mathrm{G}$ protein-gated inwardly rectifying $\mathrm{K}^{+}$channels by P2Y nucleotide receptors," Molecular Pharmacology, vol. 66, no. 3, pp. 468-477, 2004.

[97] Y. Yamashita, H. Ogawa, and N. Akaike, "ATP-induced rise in apamin-sensitive $\mathrm{Ca}^{2+}$-dependent $\mathrm{K}^{+}$conductance in adult rat hepatocytes," The American Journal of Physiology-Gastrointestinal and Liver Physiology, vol. 270, no. 2, pp. G307-G313, 1996.

[98] A. Bringmann, T. Pannicke, M. Weick et al., "Activation of P2Y receptors stimulates potassium and cation currents in acutely isolated human Müller (glial) cells," Glia, vol. 37, no. 2, pp. 139$152,2002$.

[99] K. W. Schicker, G. K. Chandaka, P. Geier, H. Kubista, and $\mathrm{S}$. Boehm, "P2Y1 receptors mediate an activation of neuronal calcium-dependent $\mathrm{K}^{+}$channels," Journal of Physiology, vol. 588, no. 19, pp. 3713-3725, 2010.

[100] E. Coppi, F. Pedata, and A. J. Gibb, "P2Y1 receptor modulation of $\mathrm{Ca}^{2+}$-activated $\mathrm{K}^{+}$currents in medium-sized neurons from neonatal rat striatal slices," Journal of Neurophysiology, vol. 107, no. 3, pp. 1009-1021, 2012.

[101] D. Moore, J. Chambers, H. Waldvogel, R. Faull, and P. Emson, "Regional and cellular distribution of the $\mathrm{P}_{2} \mathrm{Y}_{1}$ purinergic receptor in the human brain: Striking nearonal localisation," Journal of Comparative Neurology, vol. 421, no. 3, pp. 374-384, 2000.

[102] M.-J. Morán-Jiménez and C. Matute, "Immunohistochemical localization of the $\mathrm{P} 2 \mathrm{Y}_{1}$ purinergic receptor in neurons and glial cells of the central nervous system," Molecular Brain Research, vol. 78, no. 1-2, pp. 50-58, 2000.

[103] M. Kawamura, C. Gachet, K. Inoue, and F. Kato, "Direct excitation of inhibitory interneurons by extracellular ATP mediated by $\mathrm{P}_{2} \mathrm{Y}_{1}$ receptors in the hippocampal slice," Journal of Neuroscience, vol. 24, no. 48, pp. 10835-10845, 2004.

[104] D. N. Bowser and B. S. Khakh, "ATP excites interneurons and astrocytes to increase synaptic inhibition in neuronal networks," Journal of Neuroscience, vol. 24, no. 39, pp. 8606-8620, 2004.

[105] J. Brockhaus, D. Dressel, S. Herold, and J. W. Deitmer, "Purinergic modulation of synaptic input to Purkinje neurons in rat cerebellar brain slices," European Journal of Neuroscience, vol. 19, no. 8, pp. 2221-2230, 2004.

[106] J. Deitmer, J. Brockhaus, and D. Casel, "Modulation of synaptic activity in Purkinje neurons by ATP," Cerebellum, vol. 5, no. 1, pp. 49-54, 2006.

[107] M. Farrant and Z. Nusser, "Variations on an inhibitory theme: phasic and tonic activation of $\mathrm{GABA}_{A}$ receptors," Nature Reviews Neuroscience, vol. 6, no. 3, pp. 215-229, 2005.

[108] A. Kepecs and G. Fishell, "Interneuron cell types are fit to function,” Nature, vol. 505, no. 7483, pp. 318-326, 2014.

[109] T. F. Freund and G. Buzsáki, "Interneurons of the hippocampus," Hippocampus, vol. 6, no. 4, pp. 347-470, 1996.

[110] T. Klausberger and P. Somogyi, "Neuronal diversity and temporal dynamics: the unity of hippocampal circuit operations," Science, vol. 321, no. 5885, pp. 53-57, 2008. 
[111] J. Defelipe, P. L. López-Cruz, R. Benavides-Piccione et al., "New insights into the classification and nomenclature of cortical GABAergic interneurons," Nature Reviews Neuroscience, vol. 14, no. 3, pp. 202-216, 2013

[112] S. B. Schulz, Z.-J. Klaft, A. R. Rösler, U. Heinemann, and Z. Gerevich, "Purinergic P2X, P2Y and adenosine receptors differentially modulate hippocampal gamma oscillations," Neuropharmacology, vol. 62, no. 2, pp. 914-924, 2012.

[113] M. Bartos, I. Vida, and P. Jonas, "Synaptic mechanisms of synchronized gamma oscillations in inhibitory interneuron networks," Nature Reviews Neuroscience, vol. 8, no. 1, pp. 45-56, 2007.

[114] Z.-J. Klaft, S. B. Schulz, A. Maslarova, S. Gabriel, U. Heinemann, and Z. Gerevich, "Extracellular ATP differentially affects epileptiform activity via purinergic $\mathrm{P} 2 \mathrm{X} 7$ and adenosine $\mathrm{A} 1$ receptors in naive and chronic epileptic rats," Epilepsia, vol. 53, no. 11, pp. 1978-1986, 2012.

[115] P. Fries, "Neuronal gamma-band synchronization as a fundamental process in cortical computation," Annual Review of Neuroscience, vol. 32, pp. 209-224, 2009.

[116] C. S. Herrmann and T. Demiralp, "Human EEG gamma oscillations in neuropsychiatric disorders," Clinical Neurophysiology, vol. 116, no. 12, pp. 2719-2733, 2005.

[117] P. J. Uhlhaas and W. Singer, "Neuronal dynamics and neuropsychiatric disorders: toward a translational paradigm for dysfunctional large-scale networks," Neuron, vol. 75, no. 6, pp. 963-980, 2012.

[118] A. Posłuszny, "The contribution of electrical synapses to field potential oscillations in the hippocampal formation," Frontiers in Neural Circuits, vol. 8, article 32, 2014.

[119] C. E. Stout, J. L. Costantin, C. C. G. Naus, and A. C. Charles, "Intercellular calcium signaling in astrocytes via ATP release through connexin hemichannels," The Journal of Biological Chemistry, vol. 277, no. 12, pp. 10482-10488, 2002.

[120] S. Locovei, J. Wang, and G. Dahl, "Activation of pannexin 1 channels by ATP through P2Y receptors and by cytoplasmic calcium," FEBS Letters, vol. 580, no. 1, pp. 239-244, 2006.

[121] A. Araque, V. Parpura, R. P. Sanzgiri, and P. G. Haydon, "Tripartite synapses: glia, the unacknowledged partner," Trends in Neurosciences, vol. 22, no. 5, pp. 208-215, 1999.

[122] A. Araque, G. Carmignoto, P. G. Haydon, S. H. R. Oliet, R. Robitaille, and A. Volterra, "Gliotransmitters travel in time and space," Neuron, vol. 81, no. 4, pp. 728-739, 2014.

[123] V. Gundersen, J. Storm-Mathisen, and L. H. Bergersen, "Neuroglial transmission," Physiological Reviews, vol. 95, no. 3, pp. 695-726, 2015.

[124] R. Káradóttir, P. Cavelier, L. H. Bergersen, and D. Attwell, "NMDA receptors are expressed in oligodendrocytes and activated in ischaemia," Nature, vol. 438, no. 7071, pp. 1162-1166, 2005.

[125] C. J. L. Sogn, M. Puchades, and V. Gundersen, "Rare contacts between synapses and microglial processes containing high levels of Ibal and actin-a postembedding immunogold study in the healthy rat brain," European Journal of Neuroscience, vol. 38, no. 1, pp. 2030-2040, 2013.

[126] J. T. Porter and K. D. McCarthy, "Hippocampal astrocytes in situ respond to glutamate released from synaptic terminals," Journal of Neuroscience, vol. 16, no. 16, pp. 5073-5081, 1996.

[127] O. Pascual, K. B. Casper, C. Kubera et al., "Astrocytic purinergic signaling coordinates synaptic networks," Science, vol. 310, no. 5745, pp. 113-116, 2005.
[128] S. Koizumi, "Synchronization of $\mathrm{Ca}^{2+}$ oscillations: involvement of ATP release in astrocytes," FEBS Journal, vol. 277, no. 2, pp. 286-292, 2010.

[129] E. S. Vizi, Non-Synaptic Interactions between Neurons: Modulation of Neurochemical Transmission, John Wiley \& Sons, London, UK, 1984.

[130] L. F. Agnati, D. Guidolin, M. Guescini, S. Genedani, and K. Fuxe, "Understanding wiring and volume transmission," Brain Research Reviews, vol. 64, no. 1, pp. 137-159, 2010.

[131] Y. Yamazaki, K. Kaneko, S. Fujii, H. Kato, and K.-I. Ito, "Longterm potentiation and long-term depression induced by local application of ATP to hippocampal CA1 neurons of the guinea pig," Hippocampus, vol. 13, no. 1, pp. 81-92, 2003.

[132] S. Fujii, "ATP- and adenosine-mediated signaling in the central nervous system: the role of extracellular ATP in hippocampal long-term potentiation," Journal of Pharmacological Sciences, vol. 94, no. 2, pp. 103-106, 2004.

[133] H. Ikeda, M. Tsuda, K. Inoue, and K. Murase, "Long-term potentiation of neuronal excitation by neuron-glia interactions in the rat spinal dorsal horn," European Journal of Neuroscience, vol. 25, no. 5, pp. 1297-1306, 2007.

[134] J. A. Sim, S. Chaumont, J. Jo et al., "Altered hippocampal synaptic potentiation in $\mathrm{P}_{2} \mathrm{X}_{4}$ knock-out mice," Journal of Neuroscience, vol. 26, no. 35, pp. 9006-9009, 2006.

[135] J.-T. Pougnet, E. Toulme, A. Martinez, D. Choquet, E. Hosy, and E. Boué-Grabot, "ATP P2X receptors downregulate AMPA receptor trafficking and postsynaptic efficacy in hippocampal neurons," Neuron, vol. 83, no. 2, pp. 417-430, 2014.

[136] Y. Pankratov, U. Lalo, O. A. Krishtal, and A. Verkhratsky, "P2X receptors and synaptic plasticity," Neuroscience, vol. 158, no. 1, pp. 137-148, 2009.

[137] Y. Yamazaki, S. Fujii, T. Nakamura et al., "Changes in $\left[\mathrm{Ca}^{2+}\right]_{\mathrm{i}}$ during adenosine triphosphate-induced synaptic plasticity in hippocampal CA1 neurons of the guinea pig," Neuroscience Letters, vol. 324, no. 1, pp. 65-68, 2002.

[138] Y. V. Pankratov, U. V. Lalo, and O. A. Krishtal, "Role for P2X receptors in long-term potentiation," Journal of Neuroscience, vol. 22, no. 19, pp. 8363-8369, 2002.

[139] Y. Wang, J. Mackes, S. Chan et al., "Impaired long-term depression in P2X3 deficient mice is not associated with a spatial learning deficit," Journal of Neurochemistry, vol. 99, no. 5, pp. 1425-1434, 2006.

[140] Y. Wang, N. J. Haughey, M. P. Mattson, and K. Furukawa, "Dual effects of ATP on rat hippocampal synaptic plasticity," NeuroReport, vol. 15, no. 4, pp. 633-636, 2004.

[141] H. Viswanath, A. Q. Carter, P. R. Baldwin, D. L. Molfese, and R. Salas, "The medial habenula: still neglected," Frontiers in Human Neuroscience, vol. 7, article 931, 2014.

[142] G. D. Price, S. J. Robertson, and F. A. Edwards, "Long-term potentiation of glutamatergic synaptic transmission induced by activation of presynaptic P2Y receptors in the rat medial habenula nucleus," European Journal of Neuroscience, vol. 17, no. 4, pp. 844-850, 2003.

[143] M. E. Rubio and F. Soto, "Distinct localization of P2X receptors at excitatory postsynaptic specializations," Journal of Neuroscience, vol. 21, no. 2, pp. 641-653, 2001.

[144] J. Mateo, M. García-Lecea, M. T. Miras-Portugal, and E. Castro, " $\mathrm{Ca}^{2+}$ signals mediated by P2X-type purinoceptors in cultured cerebellar Purkinje cells," Journal of Neuroscience, vol. 18, no. 5, pp. 1704-1712, 1998. 
[145] S. Kirischuk, V. Matiash, A. Kulik, N. Voitenko, P. Kostyuk, and A. Verkhratsky, "Activation of $\mathrm{P}_{2}$-purino-, $\alpha_{1}$-adreno and $\mathrm{H}_{1}$ histamine receptors triggers cytoplasmic calcium signalling in cerebellar Purkinje neurons," Neuroscience, vol. 73, no. 3, pp. 643-647, 1996.

[146] M. R. S. Carmo, A. P. Simões, A. A. Fonteles, C. M. Souza, R. A. Cunha, and G. M. Andrade, "ATP P2Y1 receptors control cognitive deficits and neurotoxicity but not glial modifications induced by brain ischemia in mice," European Journal of Neuroscience, vol. 39, no. 4, pp. 614-622, 2014.

[147] Y. Chin, M. Kishi, M. Sekino et al., "Involvement of glial P2Y receptors in cognitive deficit after focal cerebral stroke in a rodent model," Journal of Neuroinflammation, vol. 10, article 95, 2013.

[148] A. M. Choo, W. J. Miller, Y.-C. Chen et al., "Antagonism of purinergic signalling improves recovery from traumatic brain injury," Brain, vol. 136, no. 1, pp. 65-80, 2013.

[149] J. Chen, Z. Tan, L. Zeng et al., "Heterosynaptic long-term depression mediated by ATP released from astrocytes," Glia, vol. 61, no. 2, pp. 178-191, 2013.

[150] S. J. Guzman, H. Schmidt, H. Franke et al., "P2Y1 receptors inhibit long-term depression in the prefrontal cortex," Neuropharmacology, vol. 59, no. 6, pp. 406-415, 2010.

[151] F. Pedata, I. Dettori, E. Coppi et al., "Purinergicsignalling in brain ischemia," Neuropharmacology, 2015.

[152] R. J. Rodrigues, A. R. Tomé, and R. A. Cunha, "ATP as a multitarget danger signal in the brain," Frontiers in Neuroscience, vol. 9, article 148, 2015.

[153] H. Franke, U. Krügel, R. Schmidt, J. Grosche, A. Reichenbach, and P. Illes, "P2 receptor-types involved in astrogliosis in vivo," British Journal of Pharmacology, vol. 134, no. 6, pp. 1180-1189, 2001.

[154] J.-J. Sun, Y. Liu, and Z.-R. Ye, "Effects of P2Y1 receptor on glial fibrillary acidic protein and glial cell line-derived neurotrophic factor production of astrocytes under ischemic condition and the related signaling pathways," Neuroscience Bulletin, vol. 24, no. 4, pp. 231-243, 2008.

[155] A. Delekate, M. Füchtemeier, T. Schumacher, C. Ulbrich, M. Foddis, and G. C. Petzold, "Metabotropic P2Y1 receptor signalling mediates astrocytic hyperactivity in vivo in an Alzheimer's disease mouse model," Nature Communications, vol. 5, article 5422, 2014.

[156] D. Moore, S. Iritani, J. Chambers, and P. Emson, "Immunohistochemical localization of the P2Y1 purinergic receptor in Alzheimer's disease," NeuroReport, vol. 11, no. 17, pp. 3799-3803, 2000.

[157] L. Erb, C. Cao, D. Ajit, and G. A. Weisman, "P2Y receptors in Alzheimer's disease," Biology of the Cell, vol. 107, no. 1, pp. 1-21, 2015.

[158] L. T. Woods, D. Ajit, J. M. Camden, L. Erb, and G. A. Weisman, "Purinergic receptors as potential therapeutictargets in Alzheimer's disease," Neuropharmacology, 2015.

[159] T. S. Peterson, J. M. Camden, Y. Wang et al., "P2Y2 nucleotide receptor-mediated responses in brain cells," Molecular Neurobiology, vol. 41, no. 2-3, pp. 356-366, 2010.

[160] H. J. Kim, D. Ajit, T. S. Peterson et al., "Nucleotides released from $\mathrm{A} \beta_{1-42}$-treated microglial cells increase cell migration and $\mathrm{A} \beta_{1-42}$ uptake through $\mathrm{P}_{2} \mathrm{Y}_{2}$ receptor activation," Journal of Neurochemistry, vol. 121, no. 2, pp. 228-238, 2012.

[161] D. Ajit, L. T. Woods, J. M. Camden et al., "Loss of P2Y 2 nucleotide receptors enhances early pathology in the TgCRND8 mouse model of Alzheimer's disease," Molecular Neurobiology, vol. 49, no. 2, pp. 1031-1042, 2014.

[162] H.-Q. Li, C. Chen, Y. Dou et al., "P2Y 4 receptor-mediated pinocytosis contributes to amyloid beta-induced self-uptake by microglia," Molecular and Cellular Biology, vol. 33, no. 21, pp. 4282-4293, 2013.

[163] S. E. Haynes, G. Hollopeter, G. Yang et al., "The P2Y ${ }_{12}$ receptor regulates microglial activation by extracellular nucleotides," Nature Neuroscience, vol. 9, no. 12, pp. 1512-1519, 2006.

[164] S. Espada, F. Ortega, E. Molina-Jijón et al., “The purinergic P2Y13 receptor activates the Nrf2/HO-1 axis and protects against oxidative stress-induced neuronal death," Free Radical Biology and Medicine, vol. 49, no. 3, pp. 416-426, 2010. 

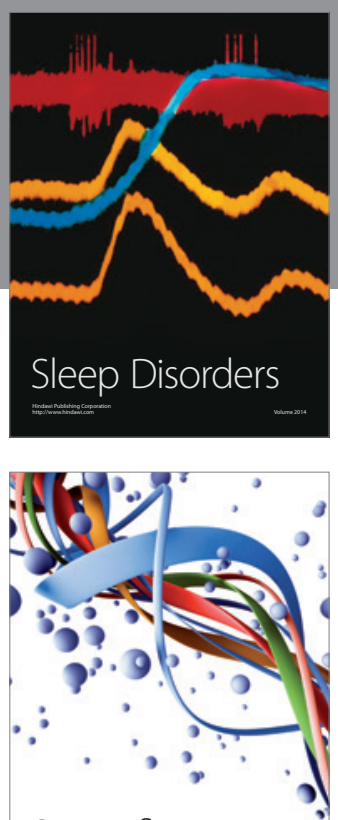

Scientifica
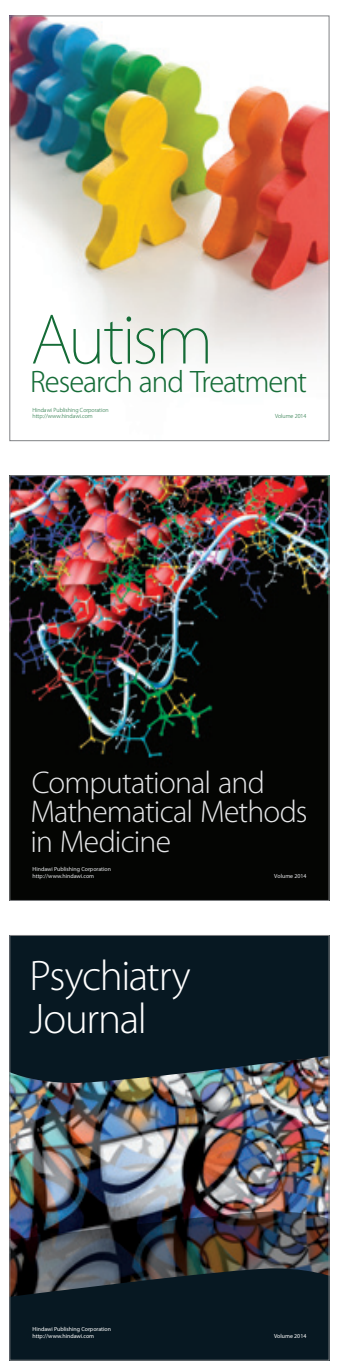
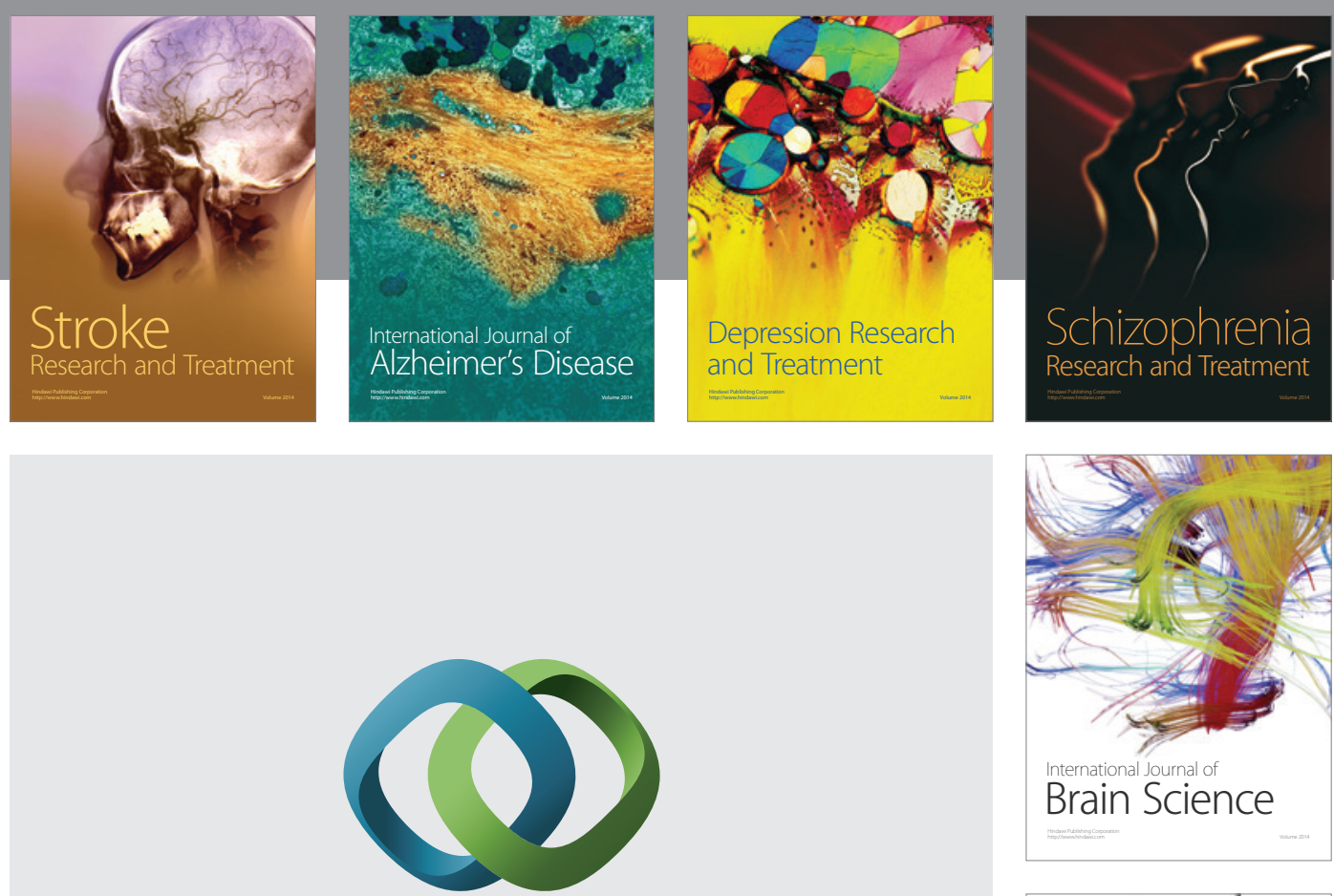

\section{Hindawi}

Submit your manuscripts at

http://www.hindawi.com
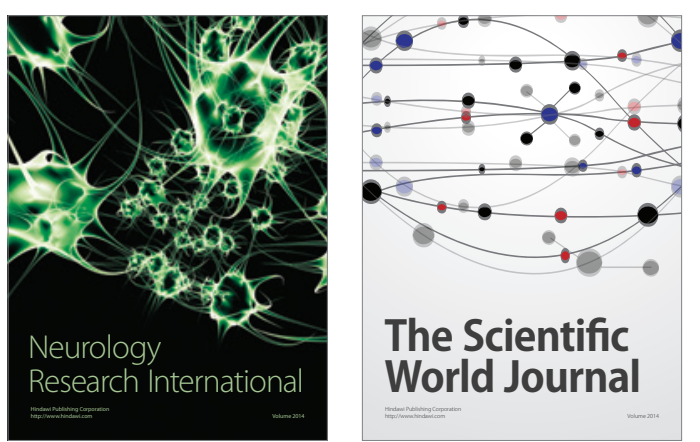

The Scientific World Journal

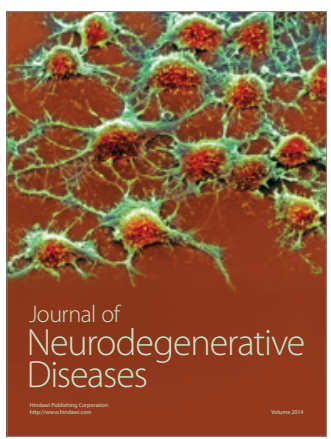

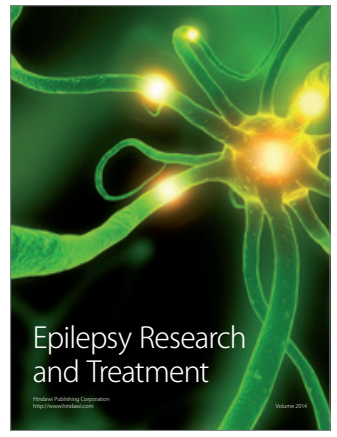

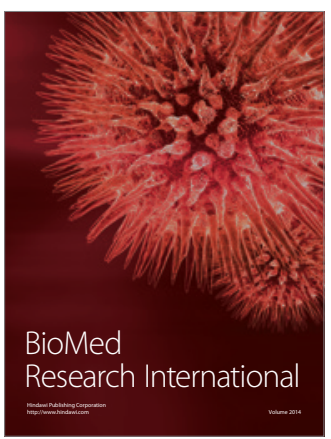

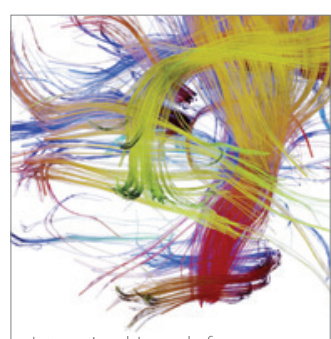

Brain Science

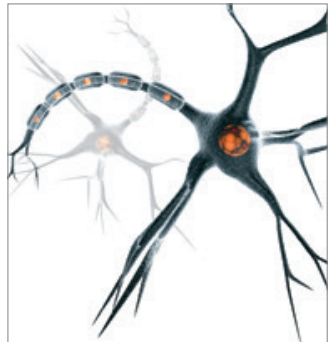

Neural Plasticity
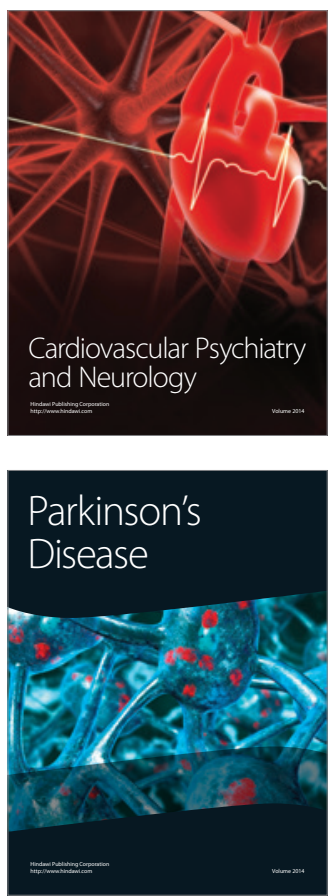